\title{
SIMULATION OF THE EFFECTS OF FOREST ROADS ON STORMFLOW GENERATION USING GIS AND 2D VADOSE ZONE HYDROLOGICAL MODEL
}

\author{
TOMÁŠ ORFÁNUS ${ }^{1 *}$, MARIÁN JENČO ${ }^{2}$, JURAJ BEBEJ ${ }^{3}$, MARTIN BENKO $^{4}$
}

${ }^{1}$ Institute of Hydrology, Slovak Academy of Sciences, Račianska 75, 83102 Bratislava, Slovak Republic; e-mail: Orfanus@uh.savba.sk

${ }^{2}$ Department of Physical Geography and Geoecology, Faculty of Natural Sciences, Comenius University in Bratislava, Bratislava, Slovak Republic

${ }^{3}$ Faculty of Forestry, Technical University in Zvolen, Zvolen, Slovak Republic

${ }^{4}$ Slovak Hydrometeorological Institute, Jeséniova 17, 83315 Bratislava, Slovak Republic

* Author for correspondence

\begin{abstract}
Orfánus T., Jenčo M., Bebej J., Benko M.: Simulation of the effects of forest roads on stormflow generation using GIS and 2D vadose zone hydrological model. Ekológia (Bratislava), Vol. 36, No. 1, p. 25-39, 2017.

There was a destructive flood on Gidra river on June induced by 104-mm rainfall during $3 \mathrm{~h}$ on 7 June 2011. The total flood discharge was estimated to be $531,000 \mathrm{~m}^{3}$. The upper part of the Gidra river catchment is forested by more than $95 \%$, but the forest floor has been disrupted to a large extent by intensive logging activities in the basin. Forest road density is up to $10 \mathrm{~km} / \mathrm{km}^{2}$ in the catchment. The field inspections in the catchments revealed that approximately $25 \%$ of forest roads have been deepened down to the less permeable subsoil directly during their construction or by subsequent traffic and soil erosion. Forest roads affect runoff generation via two mechanisms: (1) generation of infiltration-excess runoff on road surfaces and (2) capturing of hillslope surface and subsurface water by road incisions. Infiltration-excess water runoff from all compacted surfaces was estimated to be about $54,000 \mathrm{~m}^{3}$ by simply multiplying the compacted area by the difference between the precipitation and infiltration. More challenging was to quantify the transformation of hillslope water to the road-surface runoff. We have suggested the methodological approach that combines the GIS analyses of the terrain with mathematical simulations of the subsurface water exfiltration from hillslopes to the road surfaces using HYDRUS 2D model. Simulations based on the variability of slope inclinations and slope lengths within catchment revealed that drainage of the upward hillslopes by forest roads and deeper logging lines increased the forest road runoff by another 6,000-15,000 $\mathrm{m}^{3}$ of water.
\end{abstract}

Key words: forest roads, floods, Gidra river, HYDRUS 2D, surface runoff, subsurface runoff.

\section{Introduction}

\section{Main motivation}

In the afternoon of 7 June 2011 the area of Gidra river basin (and others) in Male Karpaty Mts were affected by extreme rainstorm event (Fig. 1). The resulting flood waves caused dam- 


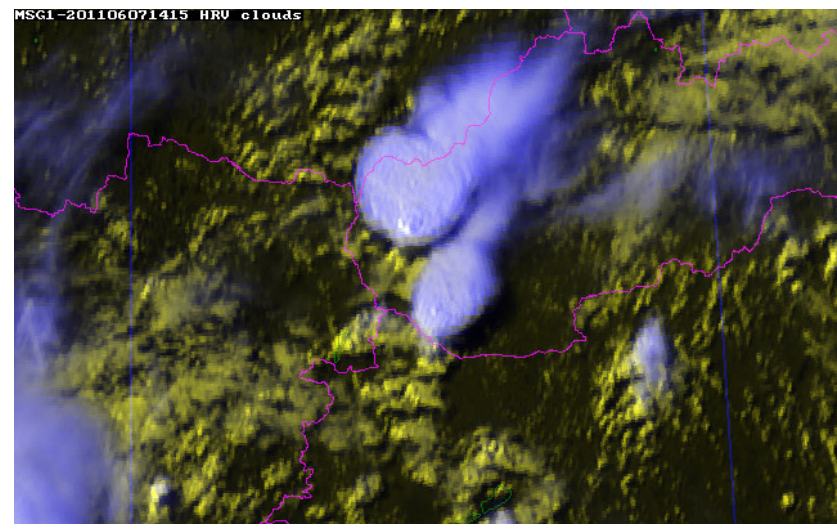

Fig. 1 . The storm cell in the highest growth stage from meteorological satellite MSG-1, product HRV + IR $10.8 \mu \mathrm{m}$. In the picture, at 14:15 UTC, it is possible to distinguish the small overshooting tops of $\mathrm{Cb}$ clouds. Adopted from Benko et al. (2013).

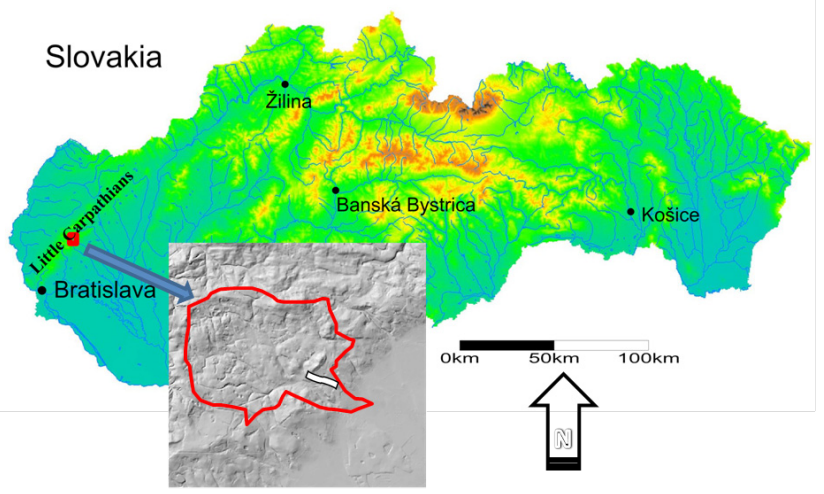

Fig. 2. Positioning of the research area (upper Gidra river basin) inside the area of Slovakia. The white rectangle indicates the village Píla. ages in the following foothill settlements: Píla, Častá, Dolany, Horné Orešany and Lošonec. The total precipitation of $104 \mathrm{~mm}$ fell during 3 $\mathrm{h}$ on already largely saturated basins, what made the commonly up-to-knee stream of Gidra river to change to a 2- to 3-m high flood wave. Unlike the village Horné Orešany in the neighbouring Parná river catchment, which was substantially protected by local water reservoir with accumulation capacity of 1 million $\mathrm{m}^{3}$ (transforming the peak of $140-50 \mathrm{~m}^{3} \mathrm{~s}^{-1}$ to 11.5 $\mathrm{m}^{3} \mathrm{~s}^{-1}$ ), this flood on Gidra resulted in vast damage of the unprotected village Píla (Fig. 2). Thanks, God, nobody was killed this time.

Similar daily rainfall totals are not exclusive in the area of Malé Karpaty Mts (Faško et al., 2006; Pecho et al., 2010). In Limbach station, the rainfall was measured be $147 \mathrm{~mm}$ in 1957 and $142 \mathrm{~mm}$ in Myjava in 1954. In Trnava-school station in 1951, it was measured be even $163 \mathrm{~mm}$. Extraordinary storms in west-

ern Slovakia occurred also in 1999, when in broader surroundings of Bratislava and Pezinok more than $150 \mathrm{~mm}$ of water fell to the ground during the single day or in 1997 with about 90 mm daily totals (Pekárová et al., 2012). According to Šamaj et al. (1985), 104-mm daily rainfall total is representative for about 50 -year repetition period in Limbach station and somewhat less than 100-year water supply in Smolenice station.

Intensive wood harvesting activities have been practised in the upper Gidra basin area during the past decades. Road networks in mountainous forest catchments may increase the peak streamflow by replacing subsurface flow paths with surface flow paths (Bowling, Lettenmaier, 1997) and by direct concentration of infiltration-excess water from their sur- 
faces and upward hillslopes. The cited authors responded this way to a broad public debate in the states of Oregon and Washington after the destructive floods in 1996. The debate concerned the extent to which clearcut logging and the construction of forest roads were to blame for the high flows and associated damage. The same ecohydrological problem has become discussed in Slovakia during the past two decades, anytime the extraordinary flood situation (no exception the one in Píla in June 2011) occurs. Wood harvesting and its effects on hydrological processes in forested basins even started to be a political issue since the governmental programme of the landscape revitalisation had been established in 2010 . Nongovernmental organisations or civic associations blame the state or private foresters for their ruthless clearcut management causing still growing frequency of floods in sub-mountainous settlements. They usually argue that a good-state forest represents the best flood-protection measure in mountainous areas at all. This is somewhat misinterpreted assumption inherited from past generations of foresters and hydrologists, who, however, considered floods triggered by the snowmelt or rain-on-snow events. No doubt, that in such situations, the effect of forest canopy could be decisive (Kattelmann, 1990; Hríbik et al., 2012).

The ownership conversion in early 1990s really brought the decrease in quality and vitality of forests in Slovakia. It is also true that during the vegetation season, the interception of rainfall in a tree crown cover influences the long-term water balance significantly, because it can integrate even $40 \%$ of the total precipitation during the summer half of the year (Knava et al., 2008; Miklánek, Pekárová, 2006). Still its immediate one-off interception capacity by single rainfall event is hardly higher than $5 \mathrm{~mm}$ what becomes insignificant by amounts counting several tens or hundreds of millimeters. Hence, when the careful harvesting is practiced and soil compaction is prevented, there is theoretically no reason to expect the significant acceleration of surface runoff (flash flood) by clearcuts during the summer stormflow events. Increased runoff or soil erosion have even not been observed on large areas affected by catastrophic wind-throw calamity in High Tatras in November 2004.

On the other hand, it has been proved many times that compacted linear surfaces originating in wood-harvesting activities are concentrating surface runoff, increase drainage density of the basin and could be source of $30-80 \%$ of sediments transported in rivers (e.g. Haupt, 1959; Hafley, 1975; Hagans et al., 1986). Further on, these sediments may cause secondary environmental problems, such as eutrophication (Kiedrzynska et al., 2008; Zalewski et al., 2010).

Rightfully the question was asked by public representatives, journalists, publicists and scientists themselves: what are the crucial causes and what measures are available to prevent the demolition of villages by floods caused by meteorological and ecohydrological conditions similar to the one in Píla village on 7 June 2011?

\section{The meteorological and hydrological description of the event from 7 June 2011}

The main synoptic structure, controlling the flow over Europe during 7 June 2011, was the cyclone over Ireland. The deepening upper level trough was spread from the aforementioned cyclone to Spain and north-west Africa. Central Europe area was at its front side. Over Central Europe area there was a slight south-western flow prevailing in the upper level of the atmosphere. The warm and moist air mass was spread over the Slovak region on 7 June 2011. 
Higher amount of humidity in the lower troposphere contributed to slight to moderate air mass instability. In later afternoon, the wind had to be turned up more to the southeast and east what could have a positive impact on the growing of massive Cumulonimbus clouds and their prolonged existence (Fig. 1). The convection temperature from morning outputs were set to about $24^{\circ} \mathrm{C}$, and in western Slovakia, this value was already reached in mentioned region at 9 UTC. At 11 UTC, it was already possible to observe the first isolated convective cells over the Malé Karpaty area by means of meteorological radar. In slight southeast flow, the Malé Karpaty Mts obstacle supported the upward movements and because of these orographical conditions, the above-mentioned convective cells were further growing and moving slightly to North. The first intensive rainfall was observed in Modra-Piesky station at 12-12:30, the immediate intensity was $100-140 \mathrm{~mm} / \mathrm{h}$ and during the next $3 \mathrm{~h}, 65 \mathrm{~mm}$ of precipitation was observed. In northwest Hungary, another convective cells were observed to create (Fig. 1) that were shifted to the north of the Malé Karpaty Mts, and at 13:30 UTC, they joined the cells situated above the ridge of the mountains. Storm cells progressed slowly to the north, but on the southern edge of multicell system, another new cells in the foothills were created. Meteorological station in Modra-Piesky observed an intensive rainfall, associated with these cells, at about 14:00-14:30 UTC and then the Častá station at 14:30 - 15:15 UTC with immediate intensity of more than $150 \mathrm{~mm} \mathrm{~h}^{-1}$ and 1-h precipitation amount of $43 \mathrm{~mm}$. Slow movement of several storm cells in combination with suitable terrain of Gidra creek valley resulted in flashflood and Gidra creek culminated at 15 UTC at level of $226 \mathrm{~cm}$, high above the third emergency level. Total 24-h rainfalls in the affected area were as follows:104 mm in Modra-Piesky, $61 \mathrm{~mm}$ in Častá, $42 \mathrm{~mm}$ in Smolenice and $31 \mathrm{~mm}$ in Modra.

It is important to notice that the raingauge station in Modra-Piesky is located on northwest ridge of Malé Karpaty Mts (Fig. 2), so there is a high probability that the southeast foothill had higher total amount of precipitation because of mentioned orographical and synoptic situation.

The Slovak Hydrometeorological Institute (SHMI) records the water level at gauging station on the Gidra river since 1956. In terms of the peak discharges during the period 19612010, the highest was $8.694 \mathrm{~m}^{3} \mathrm{~s}^{-1}$ from 7 July 1997 with 92-cm gauge water stage (Pekárová et al., 2012)

From the calculated 15-min flood hydrograph ordinates in 7 June2011 it can be stated that

- The Gidra flood runoff until midnight was 0.43 million $\mathrm{m}^{3}$, representing $13.4 \%$ of the storm rainfall, which was 3.333 million $\mathrm{m}^{3}$ of water.

- Until 7.00 am next day, the runoff volume further increased to $0.521 \mathrm{million}^{3}$, representing $16.6 \%$ of the rainfall volume.

- Direct runoff was estimated to be 0.382 million $\mathrm{m}^{3}$ of water, that is, $11.4 \%$ of the rainfall.

- Mathematical simulation (Pekárová et al., 2012) revealed that flood wave peak discharge was about $105.8 \mathrm{~m}^{3} \mathrm{~s}^{-1}$.

- $\quad$ The specific runoff peak was $3.211 \mathrm{~m}^{3} \mathrm{~s}^{-1} \mathrm{~km}^{-2}$.

\section{On processes involved in runoff generation}

Most authors reported that in natural catchments, the main contributor to discharge amounts (waves on hydrograph) is the subsurface lateral runoff (Montgomery et al., 1997; Whipkey, 
1965; Bernier, 1985; Šach et al., 2000). This can be either Darcian, transported through the soil matrix, or non-Darcian, bypassing the soil matrix via macropores and pipes (Anderson, Burt, 1990). It can reach 50-80\% (Bernier, 1985) of the total discharge during the flood. As the forest roads and logging lines are often constructed as deep trenches on the hillsides or are thus shaped by erosion, they can drain the upward slopes and (through the seepage face) transform the subsurface water to supply the road-surface runoff. Conversion of subsurface runoff to surface runoff may decrease the catchment response time and accelerate the discharge from the catchment (potential flash floods).

The magnitude of forest road influence on basin hydrology is controlled by the quantity, velocity and distribution of water travelling in the shallow subsurface (Bowling, Lettenmaier, 1997). These parameters depend on several factors. Removal or alteration of the vegetation canopy changes the soil moisture, which influences the quantity and the distribution of water available for interception by the road network. By increasing the soil moisture upslope of the road cut, clearcuts can contribute greater subsurface flow for interception by the road network (Bowling, Lettenmaier, 1997). On the other hand, higher soil moisture facilitates further water infiltration and retention in soil matrix of water-repellent soils (frequently occurring in natural catchments), thus reducing the fast subsurface runoff through preferential flow paths (Orfánus, Fodor, 2010). The changes in soil water yield for road interception after deforestation or vegetation alterations are, therefore, hardly foreseeable and cannot be generalised. Nonetheless, these changes are least persistent in high-rainfall areas, because of the faster regrowth of vegetation (Bosch, Hewlett, 1982). Preferential flow paths are generally fed through saturation excess overland flow or by drainage of saturated soil, so they can only be active during abundant water inputs. Their contribution to basin drainage during floods can be, however, substantial, depending on the connectivity of macropores and pipes. Jones and Crane (1984) reported that $46 \%$ of streamflow in an upland basin in Wales originated as pipeflow. Tsukamoto et al. (1982) found that pipeflow was responsible for even $95 \%$ of a runoff from a small granitic catchment in Japan.

Other crucial factor that influences the formation of subsurface flow paths and their contribution to channel discharge is topography. The divergent upper hillslopes descending from the tops of the hills in various directions are typical with shallower soils (low soil accumulation). Their lower moisture deficit during dry seasons is fed quickly by heavy rainfall, and such areas can occasionally exhibit relatively shorter response time (Woods, Rowe, 1996). Convergent hillslopes are a major source of subsurface runoff, as the flow from a wider contributing area is concentrated into a narrower outlet downslope. However, the moisture deficit during dry seasons is higher in deeper soils, typical for these areas, and the slope gradients of topographic hollows are lower, so the response time may increase, what can cause the secondary streamflow peak on the hydrograph (Anderson, Burt, 1978).

The depth and position of the road-cut relative to soil depth, geology and soil type are the next factors that do control the timing of subsurface response and the degree of change in catchment response time because of roads.

The surface runoff is generated on road surfaces when the precipitation rates exceed the rate of infiltration through the road surface. The process is driven by the road gradient, antecedent soil moisture, texture of the road surface material and the degree of its compaction. 
Bowling and Lettenmaier (1997) reported that the infiltration rates vary between 0.0 and $21.5 \mathrm{~mm} \mathrm{~h}^{-1}$ (on an average, $5 \mathrm{~mm} \mathrm{~h}^{-1}$ ) during a storm. Orfanus (2011) performed an irrigation experiment, where the storm rainfall event from 7 June 2011 in Píla was simulated on the forest road surfaces treated by different revitalisation measures. The inclination of the forest road was $17 \%$. The bulk density of the forest road surface material varied between 1.53 and $2.05 \mathrm{~g} \mathrm{~cm}^{-3}$. The amount of water, which infiltrated into the untreated road surface, was $19 \mathrm{~mm} / 3 \mathrm{~h}$.

\section{Objective of the research}

The objective of our research was to provide reasonable methodology for the quantification of runoff generation and transformation processes connected with wood harvesting, immoderate forest road building and destruction of soil by transits of harvesters upon the forest floor. The distributed hydraulic models at catchment scale (such as MIKE-family of models) are extremely data demanding with still high level of uncertainty involved. We, therefore, suggested the combination of GIS-based analyses of the terrain, the forest road network and the total drainage density with $2 \mathrm{D}$ mathematical modelling of water movement on slopes incised by deep forest roads. We tried to quantify the described processes on this particular flood event on Gidra river to test the applicability of suggested methodology.

\section{Material and methods}

The methodology of suggested approach can be divided into several steps, each of them connected with certain specific assumptions, simplifications or generalisations, as follows:

1. To analyse the basin area in terms of the slope (inclination) distribution and natural drainage density.

2. To map the forest road network, including the logging lines, that are the compacted linear surfaces formed by transits of heavy harvesters and tractors on the forest floor.

3. To analyse the connectivity of forest roads active in concentrated runoff formation with natural drainage paths.

4. To perform the geological and soil survey.

5. To define the 'typical' soil profile, this will be used in 2D simulations of water transport processes on slopes.

6. To calculate the amount of infiltration-excess water from all forest roads contributing to the basin drainage network and to calculate their total direct surface runoff contribution.

7. To perform mathematical simulations of runoff formation on hillslopes (with incises forest road) having different slope inclinations and slope lengths.

8. To determine the functional relationship between the amount of (hillslope) water captured by incised forest road and the slope inclination and length.

9. Accounting for the slope length and inclination distributions to calculate the total amount of hillslope water captured by forest roads.

10. To estimate the total contribution of forest roads to the flood on Gidra in June 2011.

Description of the Gidra catchment (geology, soils, drainage network)

The area of Gidra river catchment above the Píla village (Fig. 2), which was the most affected settlement during the flood in June 2011, is $32 \mathrm{~km}^{2}$. The mean annual precipitation is about $850 \mathrm{~mm}$. The catchment is forested by more than $95 \%$, but despite this fact, the event from June 2011 had a flashflood character.

The study area is part of the Male Karpaty Mts that consists of several superposed nappe units comprising pre-Alpine basement, its Mesozoic cover, superficial nappe complexes as well as the Paleogene and Lower Miocene 
complexes incorporated into the Malé Karpaty Mts during the Middle Miocene, when the Vienna and Danube Basins opened (Plašienka et al., 1991).

In the lower part of Gidra river valley emerge the rocks of pre-Alpine basement of Orešany unit to consist of the phyllites and gneisses, there. Its cover units to be represented by sandstones, quartzites, schists and dolomites of Permian to Triassic age, as well as the limestones, black shales and sandstones of Jurassic - cretaceous sequence (Plašienka et al., 1991).

The rocks of Bratislava nappe, which covers the top of Orešany unit (towards the centre of the Gidra river valley), is built up by (a) granites of Bratislava Massif, as well as the granodiorites of Badurka Massif (comprising the north part of Modranský Massif) of Variscan age, (b) contact-metamorphic rock (spotted shales, knotted schist and erlans ) to be developed on contact of granites with adjacent (c) Lower Paleozoic (Silurian to Devonian) metapelites to metapsammites and amphibolitic metabasic rock of Pezinok and Pernek units, and at least by (d) sandstones and limestones of permian to Lower Cretaceous age to represent Tatric cover units.

Northwest from Badurka Massif are present the so-called subtatric nappes of Fatricum (Vysoký nappe) and Honicum (Veterlín nappe) with dominat abundance of limestones (Michalík et al., 1993).

The soils of the upper part of the Gidra river basin are predominantly Dystric or Calcaric Cambisols, and on limestones, there are areas of Rendzic Leptosols, as well. The soils have predominantly sandyclay-loam texture with rock content usually less than $10 \%$ volumetric and granular or lumpy structure. The beech-forest floor is typically covered by 0 -to 5 -cm deep litter material in medium to strong level of decomposition.

Soil characteristics were mapped along five transects (T1-T5) during our research as is shown in Fig. 3. Particular soil profiles are illustrated in Fig. 4. Soil characteristics needed for the purpose of $2 \mathrm{D}$ hydrological modelling were depth of the soil profile, definition of particular soil horizons, texture, water retention curve and saturated hydraulic conductivity. For mathematical simulations, the representative soil profile with coupled soil characteristics was defined as follows:

- Three soil horizons were considered: Ao, B and C,

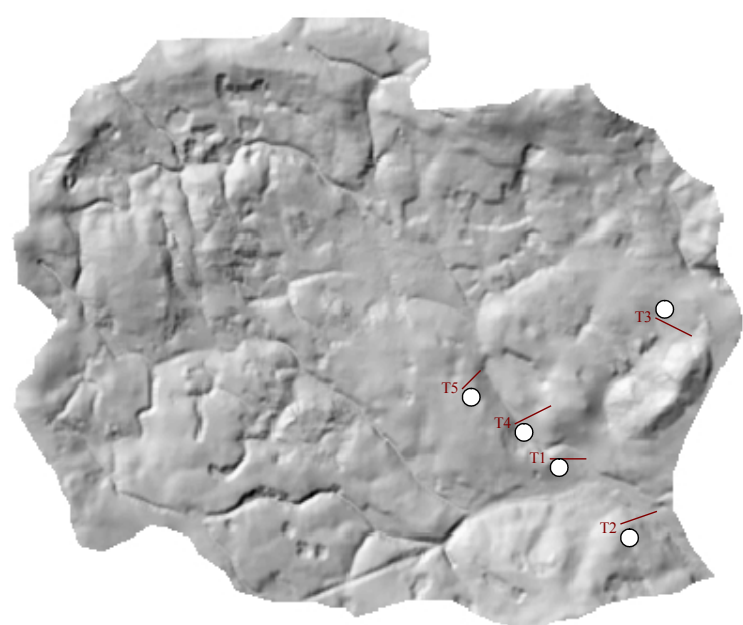

Fig. 3. The soil survey was performed in the most critical part of the catchment along five transects (T1-T5).

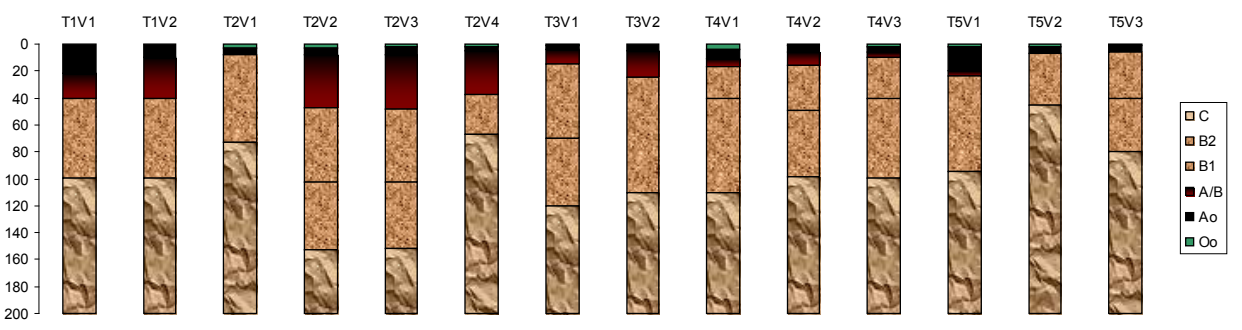

Fig. 4. Described soil profiles (T1V1-T5V3; T1V1 means Transect 1 Vertical profile 1). Soil type is Cambisol, KM. Particular soil horizons are: Oo, the forest floor litter (mostly leaves in various degree of decomposition); Ao, ochric organomineral horizon; A/B, transitional horizon; B1 and B2, cambic horizon, $\mathrm{C}$, subsoil or parent rock material. 
- The total depth down to the less permeable subsoil $(\mathrm{Ao}+\mathrm{B}): 100 \mathrm{~cm}$,

- Thickness of Ao: $25 \mathrm{~cm}$, which also incorporates the transition A/B horizon,

- Thickness of B: $75 \mathrm{~cm}$, unification of B1 and B2,

- Textural class of Ao: sandy loam soil,

- Textural class of B: sandy clay loam,

- $\quad \mathrm{C}$ - Horizon has been defined as very faintly permeable deluvial substrate.

Hydrophysical characteristics of particular soil horizons were determined by standard laboratory methods. About $100 \mathrm{~cm}^{3}$ of undisturbed core was taken from each horizon for determining the soil water retention curve using an Eijkelkamp pF-determination set. The equilibrium soil water content was determined for seven values of soil water potential $(-2,-60,-200,-800,-1,500,-3,000$ and $-15,000 \mathrm{~cm})$. The saturated soil water content, $\mathrm{q}_{\mathrm{S}}$, was determined as the equilibrium soil water content at $-2 \mathrm{~cm}$. Residual soil water content $\mathrm{q}_{\mathrm{r}}$ and parameters $\alpha$ and $\mathrm{n}$ were calculated using the program GENRET, which is a subroutine in GLOBAL model program (Majerčák et al., 1992 ) The saturated hydraulic conductivity was measured on the same samples by falling-head method. The average values of hydrophysical parameters used in HYDRUS-2D simulations are listed in Table 1.

The recognition of the terrain revealed that in (at first sight) vital compact forest canopy, there is an extremely dense network of forest roads and logging lines created by transition of heavy wood harvestors, in most parts of the upper Gidra basin (Fig. 5). The mash of the bigger roads in the left part of the catchment was identified from the airborne photographs (Google Earth) as well as by direct ground mapping with GPS-equipped motorcycles in the field. The scheme of resulting forest road network is shown in Fig. 5. The density of these linear compacted surfaces reaches up to $24 \mathrm{~km} \mathrm{~km}^{-2}$ in some parts of the catchment (Fig. 5). The width of all forest roads and logging lines was unanimously set to $4 \mathrm{~m}$. The digital elevation model of the Gidra catchment was analysed in Grass GIS environment and the map of slopes was created (Fig. 6).

T a b l e 1. Parameters of the soil water retention curve $\left(q_{r}, q_{s}, \alpha, n\right)$, saturated hydraulic conductivity $\left(K_{S} \mathrm{~cm} \mathrm{~min}{ }^{-1}\right)$ and tortuosity $(I)$ of particular soil horizons $(\mathrm{Ao}=1, \mathrm{~B}=2, \mathrm{C}=3)$.

\begin{tabular}{|c|c|r|r|r|r|r|r|}
\hline Mat & Qr & \multicolumn{1}{|c|}{ Qs } & \multicolumn{1}{|c|}{ Alpha } & $\mathrm{n}$ & Ks & \multicolumn{1}{c|}{ I } \\
\hline 1 & 0.065 & 0.41 & 0.075 & 1.89 & 0.48 & 0.5 \\
\hline 2 & 0.095 & 0.28 & 0.019 & 1.31 & 0.085 & 0.5 \\
\hline 3 & 0.001 & 0.09 & 0.019 & 1.31 & 0.0005 & 0.5 \\
\hline
\end{tabular}

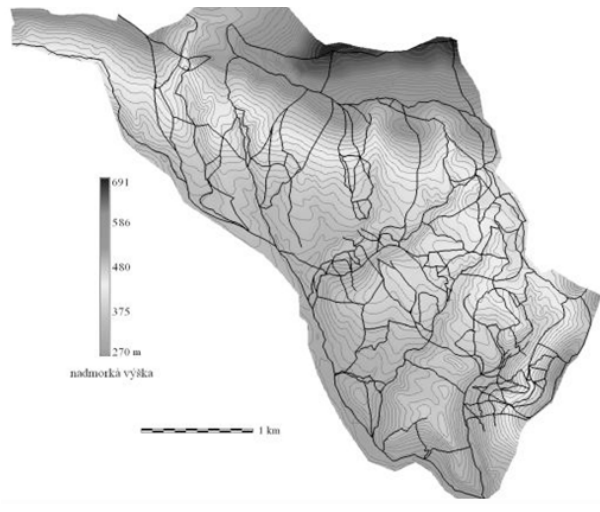

Fig. 5. The forest road network (dark lines) in the left part of the Gidra river catchment above the Píla village. The scale shows the spatial distribution of the altitude.

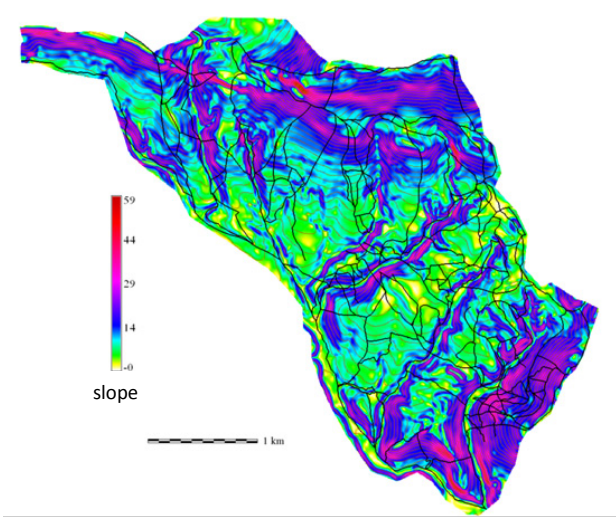

Fig. 6. The map of the slope inclinations (in degrees) in the left part of the Gidra catchment. 
The forest roads that were constructed on ridge parts of the terrain were considered not to participate on runoff generation and were mostly excluded from the final drainage network of the basin (Fig. 7). Those on inclined ridges were, however, calculated in terms of transmission of infiltration-excess water created on their surfaces into lower terrain positions feeding thus the catchment drainage network.

Simulation of drainage of the upward slopes above the forest roads

The outflow of subsurface water to the surface of incised forest road was simulated with model of water transport in soil, HYDRUS-2D (Šimůnek et al., 1999). The basic geometry of the solved domain, that is, the slope with the incised forest road was defined according to Fig. 5. The changeable variables were the slope length, $L$; slope inclination, $\alpha$; and depth of the road trench, $H$. The simulations for various upward-slope inclinations and slope lengths were performed by keeping the domain base equal to $30 \mathrm{~m}$.

Results of the $2 \mathrm{D}$ simulations with different inclinations of the terrain were then averaged for the whole area of the Gidra basin by the weighted average according to the frequency of occurrence of the particular inclination classes.

The HYDRUS-2D enabled us to perform reasonable simulations of here-defined slope processes up to the length scale of $50 \mathrm{~m}$. Larger simulation domain would request its substantial simplification as for the material distribution etc. For this reason, the slope-length frequency distribution has not been analysed either for each particular forest road or for the whole study sub-catchment area in this stage. We did the simulations for slope lengths defined as $(\mathrm{L}, \mathrm{L} / 2$, $2 / 3 \mathrm{~L}, \mathrm{~L} / 3$ ) by keeping the base of the simulation domain equal to $30 \mathrm{~m}$ (Fig. 8).

The atmospheric upper boundary condition (BC) was defined as the rain with intensity of $0.057 \mathrm{~cm} \mathrm{~min}^{-1}$ during the first $180 \mathrm{~min}$ and $0.00 \mathrm{~cm} /$ during the next $120 \mathrm{~min}$. Hence, the total amount of $104 \mathrm{~mm}$ during $3 \mathrm{~h}$ simulated the rainfall event on 7 June 2011 in Píla village. Under unsaturated soil-water status, the 'seepage face' BC defined at the forest-road's incision applies the same upper $\mathrm{BC}$ with the same rainfall intensity.

Several days with precipitation preceded the rainfall event from 7 June. The daily amount of rainfall on 6 June was $27 \mathrm{~mm}$. We, therefore, defined the initial saturation of soil as: $-100 \mathrm{~cm}$ on the lower boundary and $-200 \mathrm{~cm}$ on the upper one, which is close to field capacity.

\section{Results and discussion}

The soil profiles described along the five transects are shown in Fig. 4. They all are various subtypes of Cambisols, varying mostly in (a)

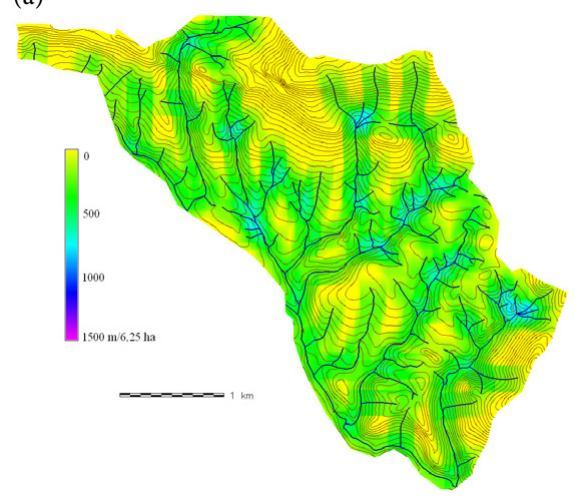

(b)
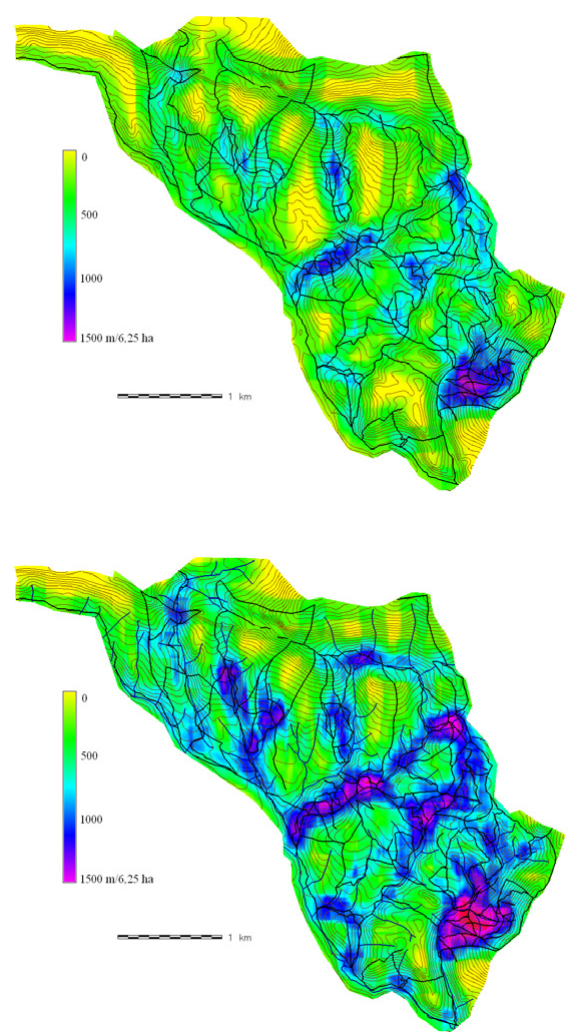

Fig. 7. The natural drainage network density (a) of the Gidra catchment above Píla village, the forest roads active in drainage of catchment with density colored scale (b) and the final catchment drainage network density integrating (a) and (b). 


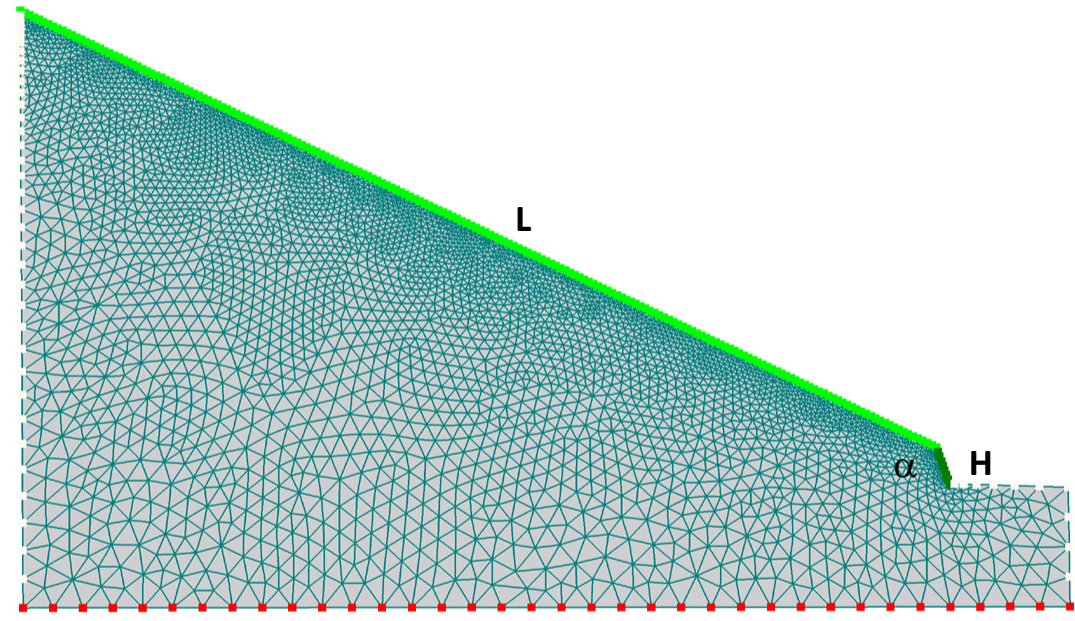

Base $=\mathbf{3 0} \mathrm{m}$

Fig. 8. The geometry and boundary conditions of the solved domain. $L$ is the length of the slope, $H$ is the depth of the road trench, $\alpha$ is the inclination of the upward slope, light green is an atmospheric BC, dark green is the 'seepage face' and red is the free drainage. The rest of the borders (white) was defined as 'no flux'.
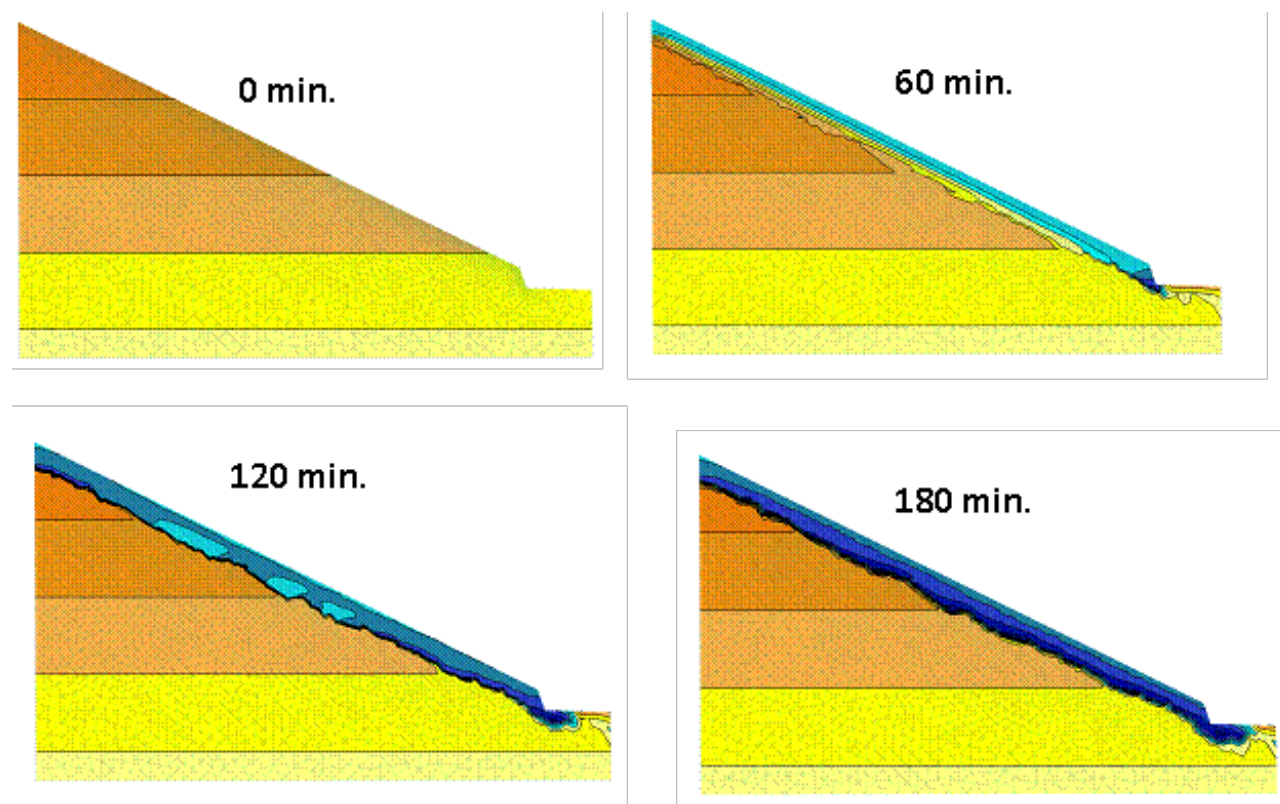

Fig. 9. Saturated zone development (dark blue) above the less permeable subsoil at different times since the beginning of rainfall event $(3 \mathrm{~h})$. The length of the slope is $30 \mathrm{~m}$. Slope inclination is $25^{\circ}$. 
the depth of soil profile and thicknesses of particular genetic horizons. The soil has typical easily drainable topsoil with quite high hydraulic conductivity and slightly compacted and significantly less permeable B horizon enriched with clay and subsoil with very poor permeability. The water holding capacity of the topsoil is high (>20 $\mathrm{mm}$ in 10-cm soil layer), whilst in B horizon, it is weak ( $<10 \mathrm{~mm}$ in $10-\mathrm{cm}$ soil layer). The retention capacity of the subsoil is similar to that of rock material.

For mathematical simulations, the representative soil profile with coupled soil characteristics was defined as follows:

- Three soil horizons were considered: Ao, B and C

- The total depth down to the less permeable subsoil $(\mathrm{Ao}+\mathrm{B}): 100 \mathrm{~cm}$,

- Thickness of Ao: $25 \mathrm{~cm}$, which also incorporates the transition A/B horizon,

- Thickness of B: $75 \mathrm{~cm}$, Unification of B1 and B2,

- Textural class of Ao: sandy loam soil,

- Textural class of B: sandy clay loam,

- $\quad \mathrm{C}$ - horizon has been defined as very faintly permeable deluvial substrate.

The hydrophysical parameters of the representative soil profile are given in Table 1. Highly permeable organomineral horizon lies on the substantially less permeable $\mathrm{B}_{\mathrm{v}}$ horizon followed by the almost impermeable subsoil. The boundaries between variably permeable soil horizons trigger the down-a-slope lateral movement of water. The preferential flow domain, which could be significant in water transfer within forest soils, was not considered in this study, as it is very hard to quantify this parameter in field conditions and will be a subject of further research in this area (tracer experiments).

If we investigate the influence of compacted linear surfaces (forest roads) on the transformation of subsurface water to surface runoff, the crucial parameters are the upward hillslope length, which is the locale of the runoff generation, its inclination and number of forest-road incisions along the runoff-contributing hillslope length. One would expect that steeper and longer the slopes are, the more water will drain out through the seepage face created by forest roads.

If we look at the Fig. 9, we can see the development of the saturated zone on the boundary between $\mathrm{B}$ and $\mathrm{C}$ soil horizons as the rainfall event proceeds. When the simulated rainfall event ceases (after $180 \mathrm{~min}$ ), the saturated zone is already developed along the whole length of the 30-m long hillslope. The mathematical simulations show that if the rain of the same intensity would last only $120 \mathrm{~min}$, the saturated zone would also develop along the whole length of the hillslope but not until the post-precipitation period (approximately $250 \mathrm{~min}$ after the rain beginning - not show in the Fig. 6). In case that the rain would last only $1 \mathrm{~h}$, subsurface runoff would be prevented (see the saturated zone (un)development after $60 \mathrm{~min}$ in Fig. 6). Taking the $\mathrm{K}_{\mathrm{S}}$ value from Table 1, one can see that in $300 \mathrm{~min}$, the water will 'travel' less than $1.5 \mathrm{~m}$ after the topsoil becomes saturated. In this way, based on this approach, only a very narrow strip of the hillslopes near the roads is contributing to the road-surface runoff during the event. It means that the more road incisions are formed on the slopes, the more subsurface water will be transformed to surface runoff via road incisions at the same time. As it was said in the introduction, preferential flow could be an important mechanism, as well. Unfortunately, this was not quantifiable in our research setup and will be considered within the follow-up research. 
Simulations were done for different hillslope inclinations. For the simulated rainfall event, no seepage-face outflow (only surface runoff) was observed until the slope inclination reached $12^{\circ}$. Once this critical slope inclination was exceeded, the linear increase of seepage face outflow with slope gradient was observed (Orfánus, Jenčo, 2014) at the distance of saturated zone formation (critical slope length). The linear dependence is the consequence of the close-to-linear relationship between the slope inclination $(\alpha)$ and the saturated zone hydraulic head gradient $(\sin \alpha)$ in the range $0^{\circ} \leq \alpha \leq 50^{\circ}$.

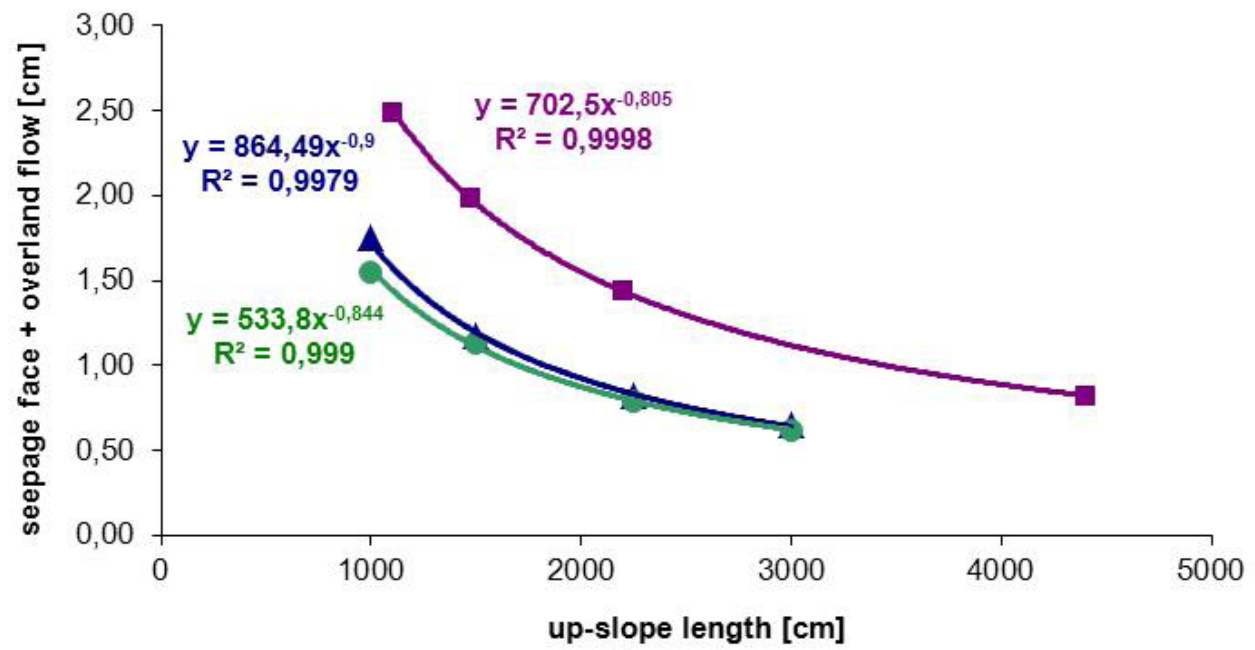

Fig. 10. The effect of hillslope length and slope inclination on the amount of water that is transported to the surface of the forest road via surface runoff and seepage face outflow. The squares are simulation results for $50^{\circ}$, triangles for $25^{\circ}$ and circles for $15^{\circ}$ slope.

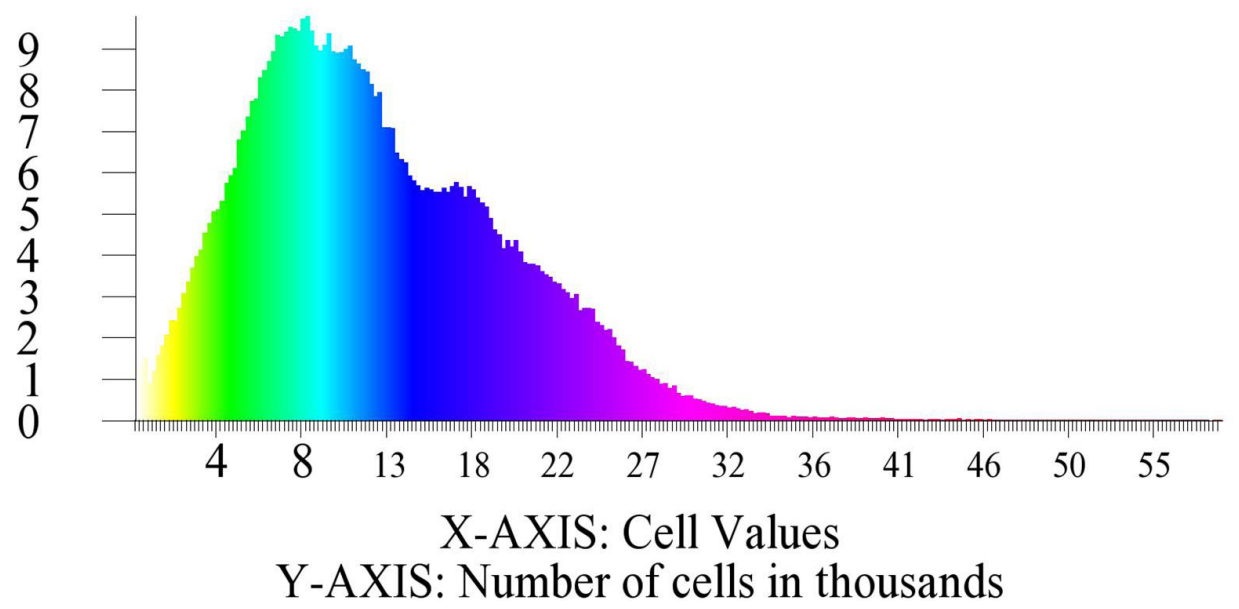

Fig. 11. Frequency distribution of the slope inclinations in upper Gidra river catchment (above the Píla village). 
The calculated values of the water amounts drifted to the surface of the forest roads via surface runoff and seepage face (subsurface runoff) are shown in Fig. 10 for different upslope lengths and inclinations. With consideration of frequency distribution of various slope inclinations in upper-Gidra catchment (Fig. 11), the results of mathematical simulations are listed in Table 2.

$\mathrm{T}$ a b le 2. The results of mathematical calculations of the hillslope surface runoff (SR) and seepage-face (SF) outflow drifted to the forest road surface for different slope inclinations and two critical slope lengths ( $\mathrm{L}$ and $100 \mathrm{~m})$. The results are expressed in millimetres of the water column and in cubic metres (multiplied by slope length and length of the forest road network). The input rain was $104 \mathrm{~mm}$ in $3 \mathrm{~h}$.

\begin{tabular}{|c|c|c|c|c|c|}
\hline Slope inclination class & $\begin{array}{c}\text { Relative } \\
\text { frequency }\end{array}$ & \multicolumn{2}{|c|}{$\begin{array}{c}\text { SR + SF outflow } \\
\text { (slope length = L) }\end{array}$} & \multicolumn{2}{c|}{$\begin{array}{c}\text { SR and SF outflow } \\
\text { (slope length = 100m) }\end{array}$} \\
\hline$<12^{\circ}$ & 0.513 & $1.40 \mathrm{~mm}$ & $861 \mathrm{~m}^{3}$ & $0.64 \mathrm{~mm}$ & $1,313 \mathrm{~m}^{3}$ \\
\hline $12-20^{\circ}$ & 0.3305 & $6.17 \mathrm{~mm}$ & $2,447 \mathrm{~m}^{3}$ & $2.17 \mathrm{~mm}$ & $2,869 \mathrm{~m}^{3}$ \\
\hline $20-35^{\circ}$ & 0.161 & $6.52 \mathrm{~mm}$ & $1,260 \mathrm{~m}^{3}$ & $2.24 \mathrm{~mm}$ & $1,443 \mathrm{~m}^{3}$ \\
\hline $35-50^{\circ}$ & 0.0035 & $12 \mathrm{~mm}$ & $50 \mathrm{~m}^{3}$ & $4.23 \mathrm{~mm}$ & $59 \mathrm{~m}^{3}$ \\
\hline$>50^{\circ}$ & 0.0003 & $0.00 \mathrm{~mm}$ & $0.00 \mathrm{~m}^{3}$ & $0.00 \mathrm{~mm}$ & $0.00 \mathrm{~m}^{3}$ \\
\hline $\begin{array}{c}\text { SUME calculated for } \\
100 \mathrm{~m} \text { long upslope area }\end{array}$ & - & - & $15,392 \mathrm{~m}^{3}$ & - & $5,647 \mathrm{~m}^{3}$ \\
\hline
\end{tabular}

The total length of forest road network was estimated to be $160 \mathrm{~km}$. Considering 4-m average width of each forest road, their total area is about $0.64 \mathrm{~km}^{2}$. It means that about $66,560 \mathrm{~m}^{3}$ of water fall on their surface during the 7 June 2011 storm. If we assume that $81 \%$ of this water had flown down (Orfánus, 2011) to the valley, it represents $54,000 \mathrm{~m}^{3}$ of water as direct contribution to flood. About 25\% (visual recognition in field) of all compacted linear surfaces (mostly forest roads) in the upper Gidra catchment are deep enough to cause the effect of subsurface water transformation to surface runoff. Considering that each of these forest roads drain the upward slope of maximum $100 \mathrm{~m}$, the amount of water transformed to surface runoff because of forest roads may range between 5,638 and 15,392 $\mathrm{m}^{3}$ depending on number of slope incisions $(1-3)$ at this runoff-active distance $(100 \mathrm{~m})$. This is substantially more conservative estimate than we did in the first approximation (Orfánus, Jenčo, 2014) for the average slope inclination $\left(56,000 \mathrm{~m}^{3}\right)$.

The total contribution of forest roads to the flood discharge is estimated by using modelling approach to be $60,000-70,000 \mathrm{~m}^{3}$, that is, up to $20 \%$ of the direct runoff. It must be stated, however, that if preferential flow will be considered, this value may increase dramatically. In follow-up research, we will focus on the diversification of soil properties, more detailed specification of the forest roads' morphology and the slope analysis above each particular forest road. The applicability of multi-domain soil models will be also deliberated.

\section{Conclusion}

The effect of forest roads on runoff generation grounds in two processes: first, the surface runoff is formed directly on forest road surfaces when the precipitation rates exceed the 
rate of infiltration through the road surface; and second, the subsurface flow paths can be replaced with surface flow paths when the forest roads are shaped as slope incisions.

The contribution of these processes to flood discharges can be substantial. Considering published researches on Rocky Mt and Cascades in the United States and our research on the river Gidra, this can amount to $10-30 \%$ of the direct runoff during the flood events.

The seepage face outflow of water via forest road incisions (transformation of subsurface flow to surface runoff) is controlled by rainfall history, the hydraulic conductivity of soil, the slope inclination and the slope length. All these factors determine the here-defined 'critical length of the upward slope' above the forest road incision to which the continuous water table (above the less permeable subsoil) may develop. Once the critical slope length is determined for the specific rainfall, specific soil and the specific slope inclination, it can be the useful characteristics of the forest-road network configuration in forest management practice.

\section{Acknowledgements}

This research was supported by the (Funding agency VEGA) under Grant ([number 2/0152/15) and (Funding agency ERDF) under Grant (number ITMS 26220120062).

\section{References}

Anderson, M.G. \& Burt T.P. (1978). The role of topography in controlling throughflow generation. Earth Surface Processes, 3, 331-344. DOI:10.1002/esp.3290030402.

Anderson, M.G. \& Burt T.P. (1990). Subsurface runoff. In M.G. Anderson \& T.P. Burt (Eds.), Process studies in hillslope hydrology. John Wiley \& Sons Ltd.

Bernier, P.Y. (1985). Variable source areas and storm-flow generation: An update of the concept and a simulation effort. J. Hydrol., 79, 195-213. DOI:10.1016/0022-1694(85)90055-1.

Bosch, J.M. \& Hewlett J.D. (1982). A review of catchment experiments to determine the effects of vegetation changes on water yield and evapotranspiration. J. Hydrol., 55, 3-23. DOI:10.1016/0022-1694(82)90117-2.

Bowling, L.C. \& Lettenmaier D.P. (1997). Evaluation of the effects of forest roads on streamflow in Hard and Ware Creeks, Washington. Water Resources Series Technical Report. Seattle, Washington: University of Washington Department of Civil Engineering, Environmental Engineering and Science.

Faško, P., Pecho, J., Mikulová, K. \& Štastný P. (2006). Prípady vysokých denných, mesačných a sezónnych úhrnov atmosférických zrážok na východnom Slovensku na konci 20. a na začiatku 21. storočia v kontexte s historickými údajmi. In Zborník prác z medzinárodnej konferencie “Ochrana pred povodňami”. Podbanské, 4.-7.12.2006.

Hafley, W.L. (1975). Rural road systems as a source of sediment pollution - a case study. In Watershed management: symposium conducted by the Committee on Watershed Management of the Irrigation and Drainage Division of the American Society of Civil Engineers Utah Section, ASCE (pp. 393-405). New York: American Society of Civil Engineers, Committee of Watershed Management.

Hagans, D.K., Weaver, W.E. \& Madej M.A. (1986). Long term on-site and off-site effects of logging and erosion in the redwood creek basin, Northern California. In Papers presented at the American Geophysical Union meeting on cumulative effects. 9-13 December 1985, San Francisco. Technical Bulletins, 490, 38-66.

Haupt, H.F. (1959). Road and slope characteristics affecting sediment movement from logging roads. Journal of Forestry, 57(5), 329-339.

Hríbik, M., Vida, T., Škvarenina, J., Škvareninová, J. \& Ivan L. (2012). Hydrological effects of Norway spuce and European beech on snow cover in a mid-mountain region of the Polana Mts., Slovakia. Journal of Hydrology and Hydromechanics, 60, 319-332. DOI:10.2478/v10098-012-0028-x.

Jones J.A. \& Crane F.G. (1984). Pipeflow and pipe erosion in the Maesnant experimental catchment. In T.P. Burt \& D.E. Walling (Eds.), Catchment experiments in fluvial geomorphology (pp. 55-72). Cambridge: GeoBooks.

Jones, J.A \& Grant G.E. (1996). Peak flow responses to clearcutting and roads in small and large basins, western Cascades, Oregon. Water Resources Research, 32(4), 959-974. DOI:10.1029/95WR03493. 
Kattelmann, R. (1990). Effects of forest cover on a snowpack in the Sierra Nevada. In R.R.Riggins (Ed.), Watershed planning and analysis in action (pp. 276-284). New York: ASCE.

Kiedrzynska, E., Kiedrzynski, M. \& Zalewski M. (2008). Flood sediment deposition and phosphorus retention in a lowland river floodplain: impact on water quality of a reservoir, Sulejow, Poland. Ecohydrol. Hydrobiol., 8(2-4), 281-289. DOI:10.2478/v10104-009-0022-z.

Majerčák, J. \& Novák V. (1992). Simulation of the soil-water dynamics in the root zone during the vegetation period. I. The mathematical model. Vodohospodársky Časopis, 40(3), 299-315.

Michalík, J., Masaryk, P., Lintnerová, O., Soták, J., Jendrejáková, O., Papšová, J. \& Buček S. (1993). Facies, paleogeography and diagenetic evolution of the Ladinian/Carnian Veterlín Reef Complex, Malé Karpaty Mts (Western Carpathians). Geologica Carpathica, 44(1), 17-34.

Miklánek, P. \& Pekárová P. (2006). Odhad intercepcie v experimentálnych mikropovodiach ÚH SAV so smrekovou a hrabovou monokultúrou. Journal of Hydrology and Hydromechanics, 54(2), 123-136.

Montgomery, D.R., Dietrich, W.E., Torres, T., Prestrud Anderson, S., Heffner, J.T. \& Loague K. (1997). Hydrologic response of a steep, unchanneled valley to natural an applied ranfall. Water Resources Research, 33(1), 91-109. DOI:10.1029/96WR02985.

Orfánus, T. \& Fodor N. (2010). K problematike protipovodňovej funkcie lesa v Tatrách. In Štúdie o Tatranskom národnom parku: monografická štúdia o dôsledkoch vetrovej kalamity z roku 2004 na prírodné prostredie Vysokých Tatier (pp. 99-108). Kežmarok: Štátne lesy TANAP-u.

Orfánus, T. (2011). Oficiálna správa o výsledkoch testu protipovodňovej a protieróznej účinnosti dvoch technických opatrení, ktoré boli zrealizované ako pilotné projekty nad obcou Ťahanovce. Bratislava: ÚH SAV.

Orfánus, T. \& Jenčo M. (2014). Transformation of subsurface flow to surface runoff by forest roads and its contribution to destructive flood in Píla village in June 2011. In K. Brych \& M. Tesař (Eds.), Hydrologie malého povodí 2014 (pp. 352-358). Praha: Ústav pro hydrodynamiku AV ČR.

Pecho, J., Faško, P., Gaál, L., Mikulová, K., Nejedlík, P., Lapin, M., Bochníček, O.\& Štastný P. (2010). Statistical and frequency analysis of extreme 2-days and 5-days precipitation totals in western Slovakia within the 1951-2009 period. In Abstracts of the Scientific Programme, Tenth Annual Meeting of the European Meteorological Society, Eighth European Conf, on Applied Climatology (ECAC). 13.-17. September 2010, Zürich.

Pekárová, P., Svoboda, A., Miklánek, P., Škoda, P., Halmová, D. \& Pekár J. (2012). Estimating flash flood peak discharge in Gidra and Parna basin: case study for the 7-8 June 2011 flood. Journal of Hydrology and Hydromechanics, 60(3), 206-216. DOI:10.2478/v10098-012-0018-z.

Plašienka, D., Michalík, J., Kováč, M., Gross, P. \& Putiš M. (1991). Paleotectonic evolution of the Malé Karpaty Mts. - an overview. Geologica Carpathica, 42, 195-208.

Simůnek, J., Sejna, M. \& van Genuchten M.Th. (1999). The Hydrus-2D software package for simulating two-dimensional movement of water, heat, and multiple solutes in variably saturated media. Version 2.0, IGWMC - TPS - 53. Colorado: International Ground Water Modeling Center, Colorado School of Mines, Golden.

Šach, F., Kantor, P. \& Černohous V. (2000). Forest ecosystems, their management by man and floods in the Orlicke hory Mts in summer 1997. Ekológia (Bratislava), 19, 72-90.

Šamaj, F., Valovič, Š. \& Brázdil R. (1985). Denné úhrny zrážok s mimoriadnou výdatnostou v ČSSR v období 1901-1980. Zborník Prác SHMÚ, 24.

Tsukamoto, Y., Ohta, T. \& Nogucji H. (1982). Hydrological and geomorphological studies of debris slides on forested hillslopes in Japan. In Recent developments in the Explanation and Predication of Erosion and Sediment Yield (Proceedings of the Exeter Symposium). IAHS Publ., 137, 89-98.

Whipkey, R.Z. (1965). Subsurface stormflow from forested slopes. IASH Bulletin, 10, 74-85.

Woods, R. (1996). The changing spatial variability of subsurface flow across a hillside. Journal of Hydrology (NZ), 35(1), 51-86.

Zalewski, M., Urbaniak, M. \& Negussie Y.Z. (2010). Ecohydrological systemic solutions for eduction of siltation, eutrophication and dioxin-induced toxicity. The pilot study of the Asella BioFarm Park lake, Ethiopia. Ecohydrol. Hydrobiol., 10(2-4), 363-368. DOI:10.2478/v10104-011-0027-2. 